\title{
PERAN FUNGI MIKORIZA ARBUSKULA (FMA) DAN ASAM HUMAT TERHADAP PERTUMBUHAN BALSA (Ochroma bicolor Rowlee.) PADA TANAH TERKONTAMINASI TIMBAL (Pb)
}

\section{The Role of Arbuscular Mycorrhizal Fungi (AMF) and Humid Acid Toward Balsa (Ochroma bicolor Rowlee.) Growth on Soil Contaminated by Lead (Pb)}

\author{
Fatimah Nur Istiqomaha, Sri Wilarso Budi ${ }^{\mathrm{b}}$, Arum Sekar Wulandari ${ }^{\mathrm{b}}$ \\ ${ }^{a}$ Program studi Silvikultur Tropika, Institut Pertanian Bogor, Kampus IPB Darmaga, Bogor $16680-$ \\ istiqomah.klaten@gmail.com \\ ${ }^{b}$ Departemen Silvikultur, Fakultas Kehutanan, Institut Pertanian Bogor, Kampus IPB Darmaga, Bogor 16680
}

\begin{abstract}
The aims of this research were to analyze the role of arbuscular mycorrhizal fungi (AMF) and humid acid toward balsa (Ochroma bicolor Rowlee.) growth on soil contaminated by lead $(\mathrm{Pb})$ and to analyze Pb accumulation in balsa. This study used a split split plot design. The main plot was AMF with 5 levels; without AMF (AO), AMF from secondary forest (A1), AMF from rubber natural forest (A2), AMF from oil palm plantations (A3), and AMF from rubber plantations (A4). The subplot was humic acid with 2 levels; no humic acid (BO) and $100 \mathrm{~mL}$ humic acid (B1). The sub subplot was Pb with 3 levels; 0 ppm Pb (CO), 500 ppm $\mathrm{Pb}(\mathrm{Cl})$, and $750 \mathrm{ppm} \mathrm{Pb}(\mathrm{C2})$. Observations of balsa seedlings was done until age of 22 weeks after planting in the greenhouse. Variables observed were height $(\mathrm{cm})$, diameter $(\mathrm{mm})$, shoot dry weight $(\mathrm{g})$, root dry weight $(\mathrm{g})$, FMA colonization $(\%)$, and the accumulation of $\mathrm{Pb}(\mathrm{ppm})$. The role of $\mathrm{AMF}$ and humic acid was more effective on the soil with $0 \mathrm{ppm}$ of $\mathrm{Pb}$ than at $500 \mathrm{ppm}$ of $\mathrm{Pb}$ and $750 \mathrm{ppm}$ of $\mathrm{Pb}$. AMF from rubber natural forest was the most effective AMF to increase diameter, root dry weight and shoot dry weight. Humic acid was able to increase the growth of height of $22.87 \%$ and diameter of $24.86 \%$ better than no humic acid. Pb accumulation in the entire plant tissue was more than 1000 ppm. It inhibited the growth of balsa seedlings and causing dead in $17.52 \%$ plant.
\end{abstract}

Keywords: Arbuscular Mycorrhizal Fungi, Pb, humid acid, Ochroma bicolor, phytoremediation

(Diterima: 26-12-2016; Disetujui: 13-02-2017

\section{Pendahuluan}

Logam timbal $(\mathrm{Pb})$ merupakan salah satu logam berat yang berbahaya bagi kesehatan manusia dan organisme lainnya. Logam berat $\mathrm{Pb}$ dihasilkan oleh kendaraan bermotor (Rangkuti, 2004), limbah cair industri (Haryati et al., 2012), dan paling banyak terdapat di lahan pasca tambang (Setyaningsih, 2007). Menurut Widaningrum et al., (2007), akumulasi $\mathrm{Pb}$ di dalam tubuh manusia dalam jangka lama dapat menyebabkan gangguan sistem peredaran darah, urat syaraf, dan ginjal. Sedangkan logam berat $\mathrm{Pb}$ di dalam tanah mengakibatkan toksik pada tanaman, sehingga mengganggu fotosintesis dan menghambat pertumbuhan, sebagai contoh Avicenia marina pada sedimen yang mengandung $\mathrm{Pb} 13.15$ ppm mengalami kerusakan jaringan buah dan daun (Arisandy et al., 2012) dan Mindi (Melia azedarach Linn.) pada media tailing yang mengandung $\mathrm{Pb} 172$ ppm mengakibatkan penurunan tinggi sebesar $28.4 \%$ dibandingkan kontrol (Setyaningsih, 2007).

$\mathrm{Pb}$ akan menjadi toksik jika konsentrasinya tinggi. Batas normal $\mathrm{Pb}$ pada tanah adalah $2-200 \mathrm{ppm}$ dan pada tanaman 0.2 - 20 ppm (Balai Penelitian Tanah 2009). Tingkat pencemaran $\mathrm{Pb}$ di Indonesia masih di bawah ambang batas pencemaran, namun harus tetap diwaspadai. Kayu manis (C.burmani) di sisi kiri tol Jagorawi mengakumulasi $\mathrm{Pb}$ rata-rata 7.95 ppm pada daun dan 19.59 ppm pada kulit batang (Rangkuti, 2004). Kandungan $\mathrm{Pb}$ pada tanah non-tambang di berbagai lokasi berkisar antara $0.39-1.21 \mathrm{ppm}$ (Suhariyono dan Menry, 2005), sementara itu pada tanah bekas tambang emas 172 ppm (Setyaningsih, 2007), limbah batu bara 54.26 ppm (Noviardi, 2013), dan tanah bekas tambang timah 7.7 ppm (Gedoan et al., 2011). Upaya untuk menghilangkan $\mathrm{Pb}$ dari tanah salah satunya dengan fitoremediasi. Menurut Prijambada (2006), fitoremediasi merupakan upaya untuk menghilangkan, menstabilkan atau menghancurkan bahan pencemar baik berupa senyawa organik maupun anorganik menggunakan tumbuhan.

Jenis tumbuhan yang mampu mengakumulasi logam berat $\mathrm{Pb}$ umumnya berupa tumbuhan bawah dan tanaman hias, seperti sambang dara (Excoecaria cochinensis), hanjuang (Cordyline fruicosa), dan Aglaonema (Haryanti et al., 2013). Penggunaan jenis pohon kehutanan seperti Balsa (Ochroma bicolor Rowlee.) yang dikenal sebagai jenis cepat tumbuh atau fast growing spesies dan tergolong tanaman reboisasi sebagai akumulator logam berat $\mathrm{Pb}$ belum pernah diuji. Kayu balsa dimanfaatkan untuk pelampung kapal, sebagai isolator, dan bahan pembuatan pulp (Alrasyid, 1996). Tanaman cepat tumbuh cocok digunakan sebagai fitoremediasi logam berat karena memiliki biomassa dan transpirasi tinggi, serta sistem perakaran yang luas (Bissonnette et al., 2010). 
Asam humat dan Fungi Mikoriza Arbuskula (FMA) ditambahkan pada media tanah yang tercemar logam berat $\mathrm{Pb}$ untuk menunjang pertumbuhan balsa. Asam humat merupakan bio-organik yang berfungsi sebagai pembenah tanah. Manfaat asam humat menurut Karti dan Setiadi (2011) antara lain: melarutkan mineral yang tidak tersedia, meningkatkan penyerapan unsur hara, memperbaiki kesuburan tanah, serta memperbaiki pertumbuhan, kesehatan, dan kualitas dari tanaman. Fungi Mikoriza Arbuskula (FMA) merupakan simbiosis mutualisme antara akar tanaman tinggat tinggi dengan fungi. Menurut Arisusanti dan Purwani (2013), FMA dapat meningkatkan toleransi tanaman terhadap logam berat $\mathrm{Pb}$, meningkatkan akumulasi $\mathrm{Pb}$ di akar, serta menghambat akumulasi $\mathrm{Pb}$ pada batang dan daun. Penelitian ini bertujuan untuk menganalisis peran FMA dan asam humat terhadap pertumbuhan semai balsa pada tanah terkontaminasi $\mathrm{Pb}$, serta menganalisis akumulasi $\mathrm{Pb}$ pada semai balsa.

\section{Metode}

\subsection{Lokasi dan Waktu Penelitian}

Penelitian ini dilakukan selama 10 bulan dari bulan Oktober 2015 sampai Juli 2016. Penanaman semai balsa dilakukan di rumah kaca Departemen Silvikultur. Isolasi spora dan analisis parameter setelah panen dilakukan di Laboratorium teknologi mikoriza dan peningkatan kualitas bibit Departemen Silvikultur IPB. Analisis tanah dan logam berat $\mathrm{Pb}$ dilakukan di Laboratorium Ilmu Tanah dan Sumberdaya Lahan IPB.

\subsection{Bahan dan Alat}

Bahan yang digunakan dalam penelitian ini adalah tanah Podsolik Merah Kuning, zeolit, pasir, benih balsa (O. bicolor), benih sorgum, inokulum FMA jenis Acaulospora, asam humat, $\left(\mathrm{PbNO}_{3}\right)_{2}$, dan aquades. Alat yang digunakan dalam penelitian ini adalah cangkul, saringan tanah, karung, plastik anti panas, mikroskop stereo, oven, autoklaf, neraca analitik, kaliper, botol film, polibag $(15 \times 20) \mathrm{cm}$, gembor, rak trapping, kulkas, cawan petri, saringan bertingkat berukuran $250 \mu \mathrm{m}, 125 \mu \mathrm{m}$, dan $63 \mu \mathrm{m}$, mikro pipet, gelas ukur, sudip, pinset, kaca preparat, dan cover glass.

\subsection{Prosedur penelitian}

a. Penangkaran FMA (Trapping) dan isolasi spora

Teknik penangkaran FMA dan isolasi spora mengikuti metode Brundrett et al., (1996). Tanah yang digunakan untuk trapping FMA berasal dari empat ekosistem di Jambi, yaitu hutan sekunder, hutan karet alam, kebun kelapa sawit, dan hutan tanaman karet. Tanah tersebut masing-masing ditimbang sebanyak 50 gram, kemudian dimasukkan dalam pot-pot kecil dengan susunan zeolit-tanah-zeolit. Benih sorgum kemudian disapih pada media tersebut dan dirawat selama 3 bulan untuk kemudian dilakukan isolasi spora. Spora disaring menggunakan saringan bertingkat dengan diameter $250 \mu \mathrm{m}, 125 \mu \mathrm{m}$, dan 63 $\mu \mathrm{m}$ di bawah air mengalir, kemudian spora dipisahkan berdasarkan genus yang dominan (Acaulospora) sebanyak 30 spora/botol.

\section{b. Sterilisasi tanah dan persiapan media}

Tanah podsolik merah kuning diambil dari Haurbentes, Jasinga pada kedalaman $1-40 \mathrm{~cm}$. Tanah dikeringanginkan selama 7 hari, selanjutnya diayak menggunakan saringan tanah berukuran $5 \mathrm{~mm}$. Tanah disterilkan menggunakan autoklaf pada suhu $121{ }^{0} \mathrm{C}$ selama 15 menit. Setiap $1 \mathrm{~kg}$ tanah steril dicampur dengan $\left(\mathrm{PbNO}_{3}\right)_{2}$ dengan konsentrasi $500 \mathrm{ppm}$ dan $750 \mathrm{ppm}$, setelah 24 jam ditambahkan asam humat dengan konsentrasi $2.5 \%$ (v/v) sebanyak $100 \mathrm{~mL}$.

c. Pengecambahan, penyapihan, dan inokulasi FMA

Benih balsa direndam dalam air panas suhu $80{ }^{\circ} \mathrm{C}$ selama 12 jam, kemudian ditaburkan di atas media pasir dan tanah dengan perbandingan 1:1 (b/b). Setelah berkecambah dengan tinggi minimal $2 \mathrm{~cm}$, semai balsa disapih pada polibag. Semai balsa dibiarkan beradaptasi dalam rumah kaca kurang lebih 3 minggu, kemudian dilakukan inokulasi FMA sebanyak 30 spora/polibag. Inokulasi dilakukan dengan cara melubangi tanah sedalam jari telunjuk sampai terlihat akar utama, kemudian spora dimasukkan dalam lubang tersebut dekat dengan akar tanaman.

\subsection{Rancangan Percobaan dan Analisis data}

Rancangan percobaan pada penelitian ini menggunakan split split plot design. Petak utama adalah FMA dengan 5 taraf, yaitu: tanpa FMA (A0), FMA asal hutan sekunder (A1), FMA asal hutan alam karet (A2), FMA asal kebun kelapa sawit (A3), dan FMA asal hutan tanaman karet (A4). Anak petak adalah asam humat dengan 2 taraf, yaitu: tanpa asam humat (B0) dan asam humat $100 \mathrm{~mL}$ (B1). Anak anak petak adalah $\mathrm{Pb}$ dengan 3 taraf, yaitu: $\mathrm{Pb} 0$ ppm (C0), $\mathrm{Pb} 500$ ppm (C1), dan Pb 750 ppm (C2). Berdasarkan ketiga faktor tersebut diperoleh 30 kombinasi perlakuan dengan 5 ulangan, sehingga terdapat 150 semai balsa. Data dianalisis menggunakan sidik ragam software SAS 9.1 (SAS Institute Inc. 2004) pada taraf nyata $5 \%$, jika perlakuan berpengaruh nyata dilakukan uji lanjut Duncan.

\subsection{Variabel pengamatan}

Variabel yang diamati yaitu tinggi $(\mathrm{cm})$, diameter $(\mathrm{mm})$, berat kering pucuk $(\mathrm{g})$, berat kering akar $(\mathrm{g})$, dan akumulasi $\mathrm{Pb}(\mathrm{ppm})$. Perhitungan akumulasi $\mathrm{Pb}$ sesuai dengan rumus sebagai berikut (Hardiani, 2009).

Akumulasi $\mathrm{Pb}=\frac{\text { Berat } \mathrm{Pb} \text { pada tanaman }}{\text { Berat kering total }} \mathrm{mg} / \mathrm{kg}$ 


\section{Hasil dan Pembahasan}

Rekapitulasi sidik ragam pertumbuhan semai balsa umur 22 minggu setelah tanam (MST) dapat dilihat pada Tabel 1.

Tabel 1 menunjukkan bahwa interaksi ketiga faktor serta interaksi FMA dengan asam humat tidak berpengaruh terhadap semua parameter pengamatan. Interaksi FMA dengan $\mathrm{Pb}$ dan interaksi asam humat dengan $\mathrm{Pb}$ berpengaruh nyata terhadap berat kering pucuk dan berat kering akar. FMA berpengaruh positif terhadap pertambahan diameter dan berat kering akar.
Asam humat berpengaruh terhadap pertambahan tinggi dan diameter. $\mathrm{Pb}$ berpengaruh negatif sangat nyata terhadap seluruh parameter semai balsa umur 22 MST.

\subsection{Tinggi dan Diameter Semai Balsa}

Pemberian asam humat memberikan respon pertumbuhan positif dan $\mathrm{Pb}$ memberikan respon negatif terhadap tinggi dan diameter semai balsa, sedangkan jenis FMA menunjukkan respon yang berbeda-beda terhadap tinggi dan diameter tergantung kepada asal ekosistem FMA yang digunakan (Tabel 2).

Tabel 1. Rekapitulasi sidik ragam pertumbuhan semai balsa umur 22 MST

\begin{tabular}{|c|c|c|c|c|c|c|c|}
\hline Parameter & A & B & $\mathrm{C}$ & $\mathrm{A} \times \mathrm{B}$ & $\mathrm{A} \times \mathrm{C}$ & $\mathrm{B} \times \mathrm{C}$ & $\mathrm{A} \times \mathrm{B} \times \mathrm{C}$ \\
\hline Pertambahan tinggi $(\mathrm{cm})$ & tn & $*$ & $* *$ & tn & tn & tn & tn \\
\hline Pertambahan diameter $(\mathrm{mm})$ & $*$ & $* *$ & $* *$ & tn & tn & tn & tn \\
\hline Berat kering pucuk $(\mathrm{g})$ & tn & tn & $* *$ & tn & $*$ & $*$ & tn \\
\hline Berat kering akar $(\mathrm{g})$ & * & tn & $* *$ & tn & *** & $*$ & tn \\
\hline
\end{tabular}

Keterangan: $\mathrm{A}=\mathrm{FMA}, \mathrm{B}=$ asam humat, $\mathrm{C}=\mathrm{Pb}, * *=$ berpengaruh sangat nyata pada $(\mathrm{P} \leq 0.01), *=$ berpengaruh nyata pada $(0.01<\mathrm{P} \leq 0.05)$, dan tn= berpengaruh tidak nyata pada $(\mathrm{P}>0.05)$.

Tabel 2. Pengaruh FMA, asam humat, dan $\mathrm{Pb}$ terhadap pertumbuhan tinggi dan diameter semai balsa umur $22 \mathrm{MST}$

\begin{tabular}{|c|c|c|c|c|}
\hline Perlakuan & Tinggi $(\mathrm{cm})$ & Peningkatan $(\%)$ & Diameter $(\mathrm{mm})$ & Peningkatan $(\%)$ \\
\hline \multicolumn{5}{|l|}{ FMA } \\
\hline A0 (tanpa FMA) & $1.09^{\mathrm{a}}$ & 00.00 & $1.05^{\mathrm{ab}}$ & 0.00 \\
\hline A1 (Hutan sekunder) & $1.09^{\mathrm{a}}$ & 00.00 & $1.06^{\mathrm{ab}}$ & 7.74 \\
\hline A2 (Hutan karet alam) & $1.14^{\mathrm{a}}$ & 00.00 & $1.08^{\mathrm{a}}$ & 19.82 \\
\hline A3 (Kebun kelapa sawit) & $1.03^{\mathrm{a}}$ & 00.00 & $1.00^{\mathrm{b}}$ & -24.11 \\
\hline A4 (Hutan tanaman karet) & $1.11^{\mathrm{a}}$ & 00.00 & $1.01^{\mathrm{ab}}$ & -8.71 \\
\hline \multicolumn{5}{|l|}{ Asam humat } \\
\hline $\mathrm{B} 0(0 \mathrm{~mL})$ & $1.05^{\mathrm{b}}$ & 00.00 & $1.01^{\mathrm{b}}$ & 0.00 \\
\hline B1 (100mL) & $1.13^{\mathrm{a}}$ & 22.87 & $1.07^{\mathrm{a}}$ & 24.86 \\
\hline \multicolumn{5}{|l|}{$\mathrm{Pb}$} \\
\hline $\mathrm{C} 0(0 \mathrm{ppm})$ & $1.46^{\mathrm{a}}$ & 00.00 & $1.24^{\mathrm{a}}$ & 0.00 \\
\hline $\mathrm{C} 1(500 \mathrm{ppm})$ & $0.93^{\mathrm{b}}$ & -86.51 & $0.96^{\mathrm{b}}$ & -72.55 \\
\hline $\mathrm{C} 2(750 \mathrm{ppm})$ & $0.89^{\mathrm{b}}$ & -88.42 & $0.91^{\mathrm{b}}$ & -77.63 \\
\hline
\end{tabular}

Keterangan: Angka-angka yang diikuti oleh huruf yang sama pada kolom yang sama menunjukkan tidak berbeda nyata berdasarkan uji Duncan pada taraf $\alpha 5 \%$

Asam humat mampu meningkatkan pertumbuhan tinggi semai balsa $22.87 \%$ dan diameter $24.86 \%$ lebih baik dibandingkan tanpa asam humat (Tabel 2). Hal ini sesuai dengan penelitian (Karti et al., 2009), asam humat efektif meningkatkan tinggi tanaman jagung dan legum pada tanah tailing dan latosol. Menurut Tisdale et al. (1990), asam humat merupakan pembenah tanah yang mampu mengkhelat Al dan logam berat. Asam humat mampu menjerap unsur hara yang kemudian akan dilepaskan secara simultan saat terjadi pertukaran unsur hara dengan tanaman, sehingga meningkatkan ketersediaan hara bagi tanaman.

FMA dari hutan karet alam merupakan jenis FMA terbaik yang mampu meningkatkan pertambahan diameter semai balsa $19.82 \%$ lebih baik dibandingkan tanpa FMA dan FMA asal kebun kelapa sawit merupakan jenis FMA paling buruk yang mengakibatkan penurunan diameter sebesar $24.11 \%$ dibandingkan tanpa FMA (Tabel 2). FMA yang berasal dari ekosistem yang berbeda memiliki efektivitas yang berbeda dan jenis FMA indegenous lebih efektif daripada sumber inokulum FMA lainnya. Miska (2015) menyatakan inokulum FMA indigenous mampu meningkatkan pertumbuhan bibit aren berdasarkan parameter tinggi tanaman, panjang pelepah daun, diameter pangkal pelepah, bobot kering tajuk, biomassa total, serapan hara $\mathrm{P}$, jumlah spora, dan persen infeksi akar daripada mycofer (campuran inokulum FMA pada media zeolit). FMA yang digunakan dalam penelitian ini merupakan FMA indigenous yang berasal dari 4 ekosistem di Jambi. FMA yang berasal dari hutan karet alam merupakan isolat yang paling efektif, hal tersebut diduga karena ekosistem hutan karet alam kondisinya masih alami dan belum banyak mendapatkan gangguan manusia.

FMA berperan sebagai biofertilizer, perbaikan struktur tanah, meningkatkan penyerapan hara, melindungi tanaman dari patogen akar, dan unsur toksik seperti logam berat. FMA melindungi tanaman 
inang dari logam berat melalui efek filtrasi, menonaktifkan secara kimiawi melalui eksudat akar yang dikeluarkan tanaman inang, dan akumulasi di dalam hifa (Rossiana, 2003).

Pemberian Pb 500 ppm dan 750 ppm menurunkan pertumbuhan tinggi dan diameter semai balsa dibandingkan media tanpa $\mathrm{Pb}$ (Tabel 2). Semai balsa pada media tanpa $\mathrm{Pb}$ tumbuh normal dan pertumbuhannya cenderung lebih baik dengan penambahan FMA dan asam humat. Sementara itu pada media $\mathrm{Pb} 500$ ppm dan 750 ppm, semai balsa menunjukkan pertambahan tinggi sangat lambat, tanaman menjadi kerdil dan sebagian mati. Hal ini menunjukkan bahwa FMA dan asam humat belum berperan dalam meningkatkan pertumbuhan semai balsa pada media yang mengandung $\mathrm{Pb} 500 \mathrm{ppm}$ dan $750 \mathrm{ppm}$. Hal yang sama ditemukan pada semai mindi di tanah tailing yang mengandung $\mathrm{Pb} 172$ ppm mengalami penurunan diameter sebesar $9.7 \%$ dibandingkan media tanah kontrol. Pemberian FMA jenis NPI 126 dan mycofer pada media tanah kontrol, tailing murni, dan campuran tanah+tailing baik dengan penambahan kompos maupun tanpa kompos tidak berbeda nyata dengan semai mindi tanpa inokulasi FMA. Pertumbuhan tinggi dan diameter pada media tailing murni tidak meningkat secara signifikan, namun pertumbuhan semai mindi pada media dengan penambahan kompos cenderung lebih baik (Setyaningsih, 2007).

\subsection{Berat Kering Pucuk dan Berat Kering Akar}

Asam humat tidak berpengaruh nyata, sedangkan FMA dan $\mathrm{Pb}$ berpengaruh nyata terhadap berat kering pucuk dan berat kering akar semai balsa 22 MST. Hasil uji duncan pengaruh FMA dan $\mathrm{Pb}$ terhadap berat kering pucuk dan berat kering akar semai balsa dapat dilihat pada Tabel 3 .

Tabel 3 Pengaruh FMA dan Pb terhadap berat kering pucuk dan berat kering akar semai balsa umur 22 MST

\begin{tabular}{|c|c|c|c|c|}
\hline Perlakuan & Berat Kering Pucuk (g) & Peningkatan $(\%)$ & Berat Kering Akar (g) & Peningkatan $(\%)$ \\
\hline \multicolumn{5}{|l|}{ FMA } \\
\hline A0 (tanpa FMA) & $0.79^{\mathrm{a}}$ & 00.00 & $0.75^{\mathrm{b}}$ & 00.00 \\
\hline A1 (Hutan sekunder) & $0.79^{\mathrm{a}}$ & 00.00 & $0.73^{b}$ & -16.35 \\
\hline A2 (Hutan karet alam) & $0.83^{\mathrm{a}}$ & 00.00 & $0.82^{\mathrm{a}}$ & 144.98 \\
\hline A3 (Kebun kelapa sawit) & $0.77^{\mathrm{a}}$ & 00.00 & $0.76^{\mathrm{b}}$ & 40.14 \\
\hline A4 (Hutan tanaman karet) & $0.79^{\mathrm{a}}$ & 00.00 & $0.79^{\mathrm{ab}}$ & 94.42 \\
\hline \multicolumn{5}{|l|}{$\overline{\mathrm{Pb}}$} \\
\hline $\mathrm{C} 0(0 \mathrm{ppm})$ & $0.95^{\mathrm{a}}$ & 00.00 & $0.90^{\mathrm{a}}$ & 00.00 \\
\hline $\mathrm{C} 1$ (500 ppm) & $0.71^{\mathrm{b}}$ & -87.28 & $0.72^{\mathrm{b}}$ & -81.43 \\
\hline $\mathrm{C} 2(750 \mathrm{ppm})$ & $0.70^{\mathrm{b}}$ & -90.43 & $0.70^{\mathrm{b}}$ & -87.13 \\
\hline
\end{tabular}

Keterangan: Angka-angka yang diikuti oleh huruf yang sama pada kolom yang sama menunjukkan tidak berbeda nyata berdasarkan uji Duncan pada taraf $\alpha 5 \%$.

FMA asal hutan karet alam mampu meningkatkan berat kering akar semai balsa sebesar $144.98 \%$ dibandingkan tanpa FMA. Media yang diberi $\mathrm{Pb} 500$ ppm dan $750 \mathrm{ppm}$ menurunkan berat kering pucuk semai balsa sebesar $87.28 \%$ dan $90.43 \%$, serta menurunkan berat kering akar sebesar $81.43 \%$ dan 87.13\% dibandingkan dengan media tanpa $\mathrm{Pb}$ (Tabel 3). Pertumbuhan semai balsa pada media yang mengandung $\mathrm{Pb} 500 \mathrm{ppm}$ dan 750 ppm tergolong tidak normal, hal tersebut ditandai dengan daun yang menguning kemudian mengering dan rontok, akar pendek, serta pertumbuhannya kerdil. Haryati et al. (2012) menjelaskan $\mathrm{Pb}$ termasuk logam berat yang dapat mengganggu aktivitas enzim, sehingga reaksi kimia di dalam sel terganggu. Hal tersebut menyebabkan kerusakan jaringan epidermis, spons, dan palisade yang ditandai dengan nekrosis dan klorosis pada tanaman.

Tabel 4 menjelaskan bahwa interaksi asam humat dengan Pb 500 ppm dan 750 ppm tidak berbeda nyata terhadap berat kering pucuk dan berat kering akar, namun keduanya lebih rendah dibandingkan dengan media tanpa $\mathrm{Pb}$ Dosis asam humat $2.5 \%$ sebanyak $100 \mathrm{~mL}$ belum mampu meningkatkan berat kering akar dan berat kering pucuk semai balsa pada media terkontaminasi $\mathrm{Pb}$ tinggi. Pemberian asam humat sebaiknya disertai dengan penambahan kompos untuk menghasilkan biomassa tinggi. Menurut Iqbal (2016), dosis asam humat sebanyak $1 \mathrm{ml}$ dengan penambahan kompos $2.5 \mathrm{~kg} / \mathrm{lubang}$ tanam mampu meningkatkan berat kering akar dan pucuk sengon (Paraserienthes falcataria) pada tanah bekas tambang nikel.

Berat kering pucuk dan akar pada interaksi FMA dengan $\mathrm{Pb} 500 \mathrm{ppm}$ dan $750 \mathrm{ppm}$ lebih rendah daripada media $\mathrm{Pb} 0 \mathrm{ppm}$. Semai balsa pada media $\mathrm{Pb}$ 0 ppm tumbuh dengan normal tanpa gangguan logam berat $\mathrm{Pb}$, sedangkan pada media terkontaminasi $\mathrm{Pb}$ pertumbuhan semai balsa tertekan meskipun sudah diberi FMA (Tabel 4). Hasil penelitian ini berbeda dengan Nadeak (2015), yang menyebutkan bahwa interaksi FMA dengan $\mathrm{Pb} 400 \mathrm{ppm} / 3 \mathrm{~kg}$ tanah pada semai sengon 12 MST tidak berpengaruh nyata terhadap berat kering pucuk dan akar. Setiap jenis tanaman menunjukkan respon yang berbeda terhadap perlakuan FMA dan $\mathrm{Pb}$. Menurut Wang (2007), pengaruh mikoriza dalam pengambilan logam berat berbeda untuk setiap jenis tanaman, tergantung pada jenis mikoriza, konsentrasi dan ketersediaan logam berat serta sifat-sifat tanah. 
Interaksi asam humat dengan $\mathrm{Pb} 500$ ppm dan 750 ppm terhadap berat kering pucuk dan berat kering akar semai balsa dapat dilihat pada Tabel 4.

\subsection{Akumulasi Pb pada Semai Balsa}

Akumulasi $\mathrm{Pb}$ merupakan jumlah logam $\mathrm{Pb}$ yang terdapat di dalam tanaman. Akumulasi $\mathrm{Pb}$ tertinggi yaitu sebesar 2571.17 ppm terdapat pada interaksi perlakuan FMA asal kebun kelapa sawit tanpa asam humat pada media $\mathrm{Pb} 750$ ppm (Tabel 5). Menurut Widyati (2011), tanaman yang mampu mengakumulasi logam berat $\mathrm{Ni}, \mathrm{Cu}, \mathrm{Co}, \mathrm{Cr}$, dan $\mathrm{Pb}$ lebih dari $1000 \mathrm{mg} / \mathrm{kg}$ biomas disebut sebagai tanaman hiperakumulator. Pada kondisi cekaman $\mathrm{Pb}$ yang sangat tinggi, semai balsa mampu bertahan hidup namun pertumbuhannya terganggu dan beberapa semai balsa mati, sehingga balsa bukan tergolong tanaman hiperakumulator.

Tabel 4. Pengaruh interaksi asam humat dan FMA dengan $\mathrm{Pb}$ terhadap berat kering pucuk dan berat kering akar semai balsa umur 22 MST

\begin{tabular}{|c|c|c|c|c|c|c|}
\hline \multirow{3}{*}{ Perlakuan } & \multicolumn{6}{|c|}{$\mathrm{Pb}(\mathrm{ppm})$} \\
\hline & \multicolumn{3}{|c|}{ Berat Kering Pucuk (g) } & \multicolumn{3}{|c|}{ Berat Kering Akar (g) } \\
\hline & $\mathrm{C} 0(0)$ & C1 (500) & $\mathrm{C} 2(750)$ & $\mathrm{C} 0(0)$ & $\mathrm{C} 1(500)$ & $\mathrm{C} 2(750)$ \\
\hline \multicolumn{7}{|l|}{ Asam humat } \\
\hline B0 $(0 \mathrm{~mL})$ & $0.94^{\mathrm{a}}$ & $0.70^{\mathrm{b}}$ & $0.72^{\mathrm{b}}$ & $0.87^{\mathrm{a}}$ & $0.72^{\mathrm{b}}$ & $0.70^{\mathrm{b}}$ \\
\hline B1 $(100 \mathrm{~mL})$ & $0.96^{\mathrm{a}}$ & $0.69^{\mathrm{b}}$ & $0.73^{\mathrm{b}}$ & $0.85^{\mathrm{a}}$ & $0.69^{\mathrm{b}}$ & $0.70^{\mathrm{b}}$ \\
\hline \multicolumn{7}{|l|}{$\overline{\text { FMA }}$} \\
\hline A0 (tanpa FMA) & $0.94^{\mathrm{ab}}$ & $0.70^{\mathrm{c}}$ & $0.72^{\mathrm{c}}$ & $0.87^{\mathrm{c}}$ & $0.72^{\mathrm{bcd}}$ & $0.70^{\mathrm{bcd}}$ \\
\hline A1 (Hutan sekunder) & $0.70^{\mathrm{c}}$ & $0.87^{\mathrm{abc}}$ & $0.69^{\mathrm{c}}$ & $0.69^{\text {cd }}$ & $0.83^{\mathrm{bcd}}$ & $0.69^{\mathrm{bcd}}$ \\
\hline A2 (Hutan karet alam) & $1.05^{\mathrm{a}}$ & $0.77^{\mathrm{bc}}$ & $0.68^{\mathrm{c}}$ & $1.05 \mathrm{a}$ & $0.81^{\mathrm{bcd}}$ & $0.67^{\mathrm{d}}$ \\
\hline A3 (Hutan kelapa sawit) & $0.68^{\mathrm{c}}$ & $0.89^{\mathrm{abc}}$ & $0.68^{\mathrm{c}}$ & $0.85^{\text {bcd }}$ & $0.68^{\mathrm{d}}$ & $0.67^{\mathrm{d}}$ \\
\hline A4 (Hutan tanaman karet) & $0.90^{\mathrm{abc}}$ & $0.69^{\mathrm{c}}$ & $0.75^{\text {bc }}$ & $0.88^{\mathrm{b}}$ & $0.69^{\text {bcd }}$ & $0.74^{\mathrm{bcd}}$ \\
\hline
\end{tabular}

Keterangan: Angka-angka yang diikuti oleh huruf yang sama pada kolom yang sama menunjukkan tidak berbeda nyata berdasarkan uji Duncan pada taraf $\alpha 5 \%$

Tabel 5. Akumulasi Pb semai balsa umur $22 \mathrm{MST}$.

\begin{tabular}{|c|c|c|c|}
\hline \multicolumn{3}{|c|}{ Perlakuan } & \multirow{2}{*}{$\begin{array}{c}\text { Akumulasi Pb } \\
\text { (ppm) }\end{array}$} \\
\hline FMA & Asam humat $(\mathrm{mL})$ & $\mathrm{Pb}(\mathrm{ppm})$ & \\
\hline \multirow{6}{*}{ Tanpa FMA } & \multirow{3}{*}{ 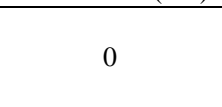 } & 0 & tidak terukur \\
\hline & & 500 & 1200.11 \\
\hline & & 750 & 1279.79 \\
\hline & \multirow{3}{*}{100} & 0 & 8.88 \\
\hline & & 500 & 1265.07 \\
\hline & & 750 & 1348.95 \\
\hline \multirow{6}{*}{ FMA asal hutan sekunder } & \multirow{3}{*}{0} & 0 & 9.00 \\
\hline & & 500 & 475.65 \\
\hline & & 750 & 1743.13 \\
\hline & \multirow{3}{*}{100} & 0 & tidak terukur \\
\hline & & 500 & 1313.04 \\
\hline & & 750 & 2252.66 \\
\hline \multirow{6}{*}{ FMA asal hutan karet alam } & \multirow{3}{*}{0} & 0 & 6.22 \\
\hline & & 500 & 940.62 \\
\hline & & 750 & 1690.00 \\
\hline & \multirow{3}{*}{100} & 0 & 4.44 \\
\hline & & 500 & 1036.75 \\
\hline & & 750 & 1294.70 \\
\hline \multirow{6}{*}{ FMA asal kebun kelapa sawit } & \multirow{3}{*}{0} & 0 & 3.56 \\
\hline & & 500 & 1180.47 \\
\hline & & 750 & 2571.17 \\
\hline & \multirow{3}{*}{100} & 0 & tidak terukur \\
\hline & & 500 & 1482.38 \\
\hline & & 750 & 1873.70 \\
\hline \multirow{6}{*}{ FMA asal hutan tanaman karet } & \multirow{3}{*}{0} & 0 & 14.20 \\
\hline & & 500 & 1394.05 \\
\hline & & 750 & 1448.20 \\
\hline & \multirow{3}{*}{100} & 0 & 25.74 \\
\hline & & 500 & 1833.30 \\
\hline & & 750 & 2091.55 \\
\hline
\end{tabular}


Akumulasi $\mathrm{Pb}$ terendah yaitu sebesar $3.56 \mathrm{ppm}$ terdapat pada interaksi perlakuan FMA asal kebun kelapa sawit tanpa asam humat pada media tanpa $\mathrm{Pb}$. Semai balsa pada media tanpa $\mathrm{Pb}$ ditemukan akumulasi $\mathrm{Pb}$ berkisar antara $3.56 \mathrm{ppm}-25.75 \mathrm{ppm}$, hal ini disebabkan media awal yang digunakan sudah mengandung $\mathrm{Pb}$ sebesar $1.32 \mathrm{ppm}$. Akumulasi $\mathrm{Pb}$ pada semai balsa lebih tinggi dari dosis $\mathrm{Pb}$ yang diberikan (Tabel 5). Peningkatan akumulasi $\mathrm{Pb}$ tersebut diduga karena faktor penyiraman yang terus dilakukan sampai 22 minggu dan udara yang juga mengandung logam berat $\mathrm{Pb}$. Selain itu tanah yang digunakan pada penelitian tergolong liat, sehingga unsur-unsur di dalam tanah terjerap dan sukar tercuci. Hal yang sama ditemukan pada tanaman kangkung darat (Ipomea reptans Poir) yang dapat mengakumulasi $\mathrm{Pb}$ sampai 1627.90 ppm pada waktu optimum 3 minggu dengan pemberian $\mathrm{Pb} 100$ ppm (Liong, 2010).

Akumulasi $\mathrm{Pb}$ pada media dengan penambahan asam humat secara umum lebih tinggi daripada tanpa asam humat (Tabel 5). Menurut Rahmawati (2011), serapan $\mathrm{Pb}$ oleh asam humat sangat dipengaruhi $\mathrm{pH}$. Hardjowigeno (1995) menambahkan tanah $\mathrm{pH}$ masam menyebabkan logam berat yang terkandung dalam medium tersebut menjadi larut dan aktif diserap oleh tanaman. Media tanah yang digunakan memiliki $\mathrm{pH}$ sangat masam yaitu 3.65 sehingga logam berat $\mathrm{Pb}$ aktif diserap oleh semai balsa.

Akumulasi $\mathrm{Pb}$ oleh semai balsa umur $22 \mathrm{MST}$ dapat dilihat pada Tabel 5. Semai balsa yang diberi FMA secara umum mampu mengakumulasi logam berat $\mathrm{Pb}$ lebih banyak dibandingkan tanpa FMA (Tabel 5). Salisbury dan Ross (1995) menjelaskan, logam berat diserap oleh akar tanaman dalam bentuk ion-ion yang larut dalam air. Tanaman dengan media yang banyak mengandung logam berat akan membentuk senyawa pengikat yang disebut fitokhelatin. Bila bertemu dengan logam berat $\mathrm{Pb}$, fitokhelatin akan membentuk ikatan sulfida di ujung belerang pada sistein dan membentuk senyawa kompleks, sehingga $\mathrm{Pb}$ akan terbawa menuju jaringan tumbuhan. Menurut Rossiana (2003), FMA akan mengakumulasi $\mathrm{Pb}$ pada bagian hifa.

Semai balsa bermikoriza mampu mengakumulasi $\mathrm{Pb}$ lebih banyak, namun FMA sendiri belum mampu meningkatkan pertumbuhan semai balsa pada kondisi cekaman $\mathrm{Pb}$ tinggi. Hal tersebut dikarenakan terjadi kompetisi serapan ion toksik dengan ion hara di dalam tanah (Rossiana, 2003). Jumlah ion hara yang diperlukan untuk pertumbuhan lebih sedikit daripada ion toksik, sehingga pertumbuhan tanaman terhambat meskipun sudah diberi perlakuan FMA.

\section{Kesimpulan dan Saran}

\subsection{Kesimpulan}

FMA dan asam humat belum menunjukkan peran pada media yang mengandung $\mathrm{Pb} 500 \mathrm{ppm}$ dan 750 ppm. FMA asal hutan karet alam paling efektif dalam meningkatkan diameter, berat kering akar, dan berat kering pucuk semai balsa. Asam humat mampu meningkatkan pertumbuhan tinggi $22.87 \%$ dan diameter $24.86 \%$ semai balsa lebih baik dibandingkan tanpa asam humat. Akumulasi $\mathrm{Pb}$ pada seluruh jaringan tanaman lebih dari 1000 ppm, hal itu membuat pertumbuhan semai balsa menjadi terhambat, tanaman menjadi kerdil dan $17.52 \%$ mati

\subsection{Saran}

Penelitian lanjutan diperlukan untuk mengetahui peran FMA dan asam humat terhadap pertumbuhan tanaman lain pada media yang mengandung $\mathrm{Pb}$ kurang dari 500 ppm. Semai balsa tidak tergolong sebagai tanaman hiperakumulator $\mathrm{Pb}$, sehingga balsa tidak direkomendasikan sebagai tumbuhan potensial untuk fitoremediasi $\mathrm{Pb}$.

\section{Daftar Pustaka}

[1] Alrasyid, H., 1996. Teknik Penanaman dan Pemungutan Kayu Balsa. Badan Penelitian dan Pengembangan Kehutanan, Bogor.

[2] Arisandy, K. R., E. Y. Herawati, E. Suprayitno, 2012. Akumulasi logam berat timbal $(\mathrm{Pb})$ dan gambaran histologi pada jaringan Avicennia marina (forsk.) Vierh di perairan Pantai Jawa Timur. Jurnal Penelitian Perikanan 1(1), pp. 1525.

[3] Arisusanti, R., K. Purwani, 2013. Pengaruh mikoriza Glomus fasciculatum terhadap akumulasi logam timbal $(\mathrm{Pb})$ pada tanaman Dahlia pinnata. Jurnal Sains dan Seni Pomits 2 (2), pp. 2337-3520.

[4] Balai Penelitian Tanah, 2009. Petunjuk Teknis: Analisis Kimia Tanah Tanaman, Air, dan Pupuk. Balai Penelitian Tanah, Bogor.

[5] Bissonnette. M., M. Arnaud, M. Labrecque, 2010. Phytoextraction of heavy metals by two Salicaceae clones in symbiosis with arbuscular mycorrhizal fungi during the second year of a field trial. Plant Soil (332), pp. 55-67.

[6] Brundrett, M., N. Bougher, B. Dell, T. Grove, N. Malajczuk, 1996. Working with mychorrizas in forestry and agriculture. Australian Centre for International Agricultural Research, Canberra.

[7] Gedoan, S., A. Hartana, Hamim, U. Widyastuti, N. Sukarno, 2011. Pertumbuhan tanaman jarak pagar (Jatropha curcas L.) pada tanah pasca tambang timah di bangka yang diberi pupuk organik. Jurnal Ilmiah Sains 11(2), pp. 181-190.

[8] Hardiani, H., 2009. Potensi tanaman dalam mengakumulasi logam $\mathrm{Cu}$ pada media tanah terkontaminasi limbah padat industri kertas. Bioscience 44(1), pp. 27-40.

[9] Hardjowigeno, S., 1995. Ilmu Tanah. Akademia Pressindo, Jakarta.

[10] Haryanti, D., D. Budianta, Salni, 2013. Potensi beberapa jenis tanaman hias sebagai fitoremidiasi logam timbal $(\mathrm{Pb})$ dalam tanah. Jurnal Penelitian Sains 16(2), pp. 52-58.

[11] Haryati, M., T. Purnomo, S. Kuntjoro, 2012. Kemampuan tanaman genjer (Limnocharis Flava (L.)Buch.) menyerap logam berat timbal $(\mathrm{Pb})$ limbah cair kertas pada biomassa dan waktu pemaparan yang berbeda. Lateral Bio 1(3).

[12] Iqbal, Iskandar, S. W. Budi, 2016. Penggunaan bahan humat dan kompos untuk meningkatkan kualitas tanah bekas tambang nikel sebagai media pertumbuhan sengon (Paraserianthes falcataria). Jurnal Pengelolaan Sumberdaya Alam dan Lingkungan 6(1), pp. 53-60.

[13] Karti, P. M. D. H., S. W. Budi, N. F. Mardatin, 2009. Optimalisasi kerja mycofer dengan augmentasi mikroorganisme tanah potensial dan asam humat untuk 
rehabilitasi lahan marginal dan terdegradasi di Indonesia. Jurnal Ilmu Pertanian Indonesia 14(2), pp. 118-131.

[14] Karti, P. M. D. H., Y. Setiadi, 2011. Respon pertumbuhan, produksi, dan kualitas rumput terhadap penambahan fungi mikoriza arbuskula dan asam humat pada tanah masam dengan alumunium tinggi. JITV. 16(2), pp. 105-112.

[15] Liong, S., 2010. Mekanisme fitoakumulasi Cd (II), Cr (IV), dan $\mathrm{Pb}$ (II) pada kangkung darat (Ipomoae reptans Poir). Disertasi. Pascasarjana Universitas Hasanuddin, Makassar.

[16] Miska M. E. L., 2015. Respon pertumbuhan bibit aren (Arenga pinnata (Wurmb) Merr.) terhadap inokulasi fungi mikoriza indigenous. tesis. Sekolah pascasarjana IPB, Bogor.

[17] Nadeak, J. O. S., Delvian, D. Elfiati, 2015. Pengaruh pemberian fungi mikoriza arbuskula (FMA) terhadap kandungan logam timbal $(\mathrm{Pb})$ pada tanaman sengon (Paraserienthes falcataria). Penorema Forestry Science Journal 4(3), pp. 1-8.

[18] Noviardi, R., 2013. Limbah batubara sebagai pembenah tanah dan sumber nutrisi: Studi kasus tanaman bunga matahari (Helianthus annus). Riset Geologi dan Pertambangan 23(1), pp. 61-72.

[19] Prijambada, I. D., 2006. Peranan mikroorganisme pada fitoremediasi tanah tercemar logam berat. Di dalam: Prosiding PIT PERMI, pp. 117-135; [terhubung berkala]. http://faperta.ugm.ac.id./download/publikasi_ [15 Desember 2015].

[20] Rahmawati, A., 2011. Pengaruh derajat keasaman terhadap adsorbsi logam kadmium(II) dan timbal(II) pada asam humat. Jurnal Penelitian Sains \& Teknologi 12(1), pp. 1-14.

[21] Rangkuti, M. N. S., 2004. Kandungan logam berat timbal dalam daun dan kulit kayu tanaman kayu manis (Cinnamomum burmani $\mathrm{Bl}$ ) pada sisi kiri jalan tol Jagorawi. Biosmart. 6(2), pp. 143-146.

[22] Rossiana, N., 2003. Penurunan Kandungan logam Berat dan Pertumbuhan Tanaman Sengon (Paraserianthes falcataria $\mathrm{L}$ (Nielsen)) Bermikoriza Dalam Medium limbah Lumpur. Universitas Padjajaran, Bandung.
[23] Salisbury, F. B., C. W. Ross, 1995. Fisiologi Tumbuhan Jilid I1. Dian R., Lukman, Sumaryono, penerjemah. Terjemahan dari: Plant Physiology Vol 2. ITB, Bandung.

[24] SAS Institute Inc., 2004. Base SAS 9.1 Procedures Guide. Cary, NC: SAS Institute Inc.

[25] Setyaningsih, L., 2007. Pemanfaatan cendawan mikoriza arbuskula dan kompos aktif untuk meningkatkan pertumbuhan semai mindi (Melia azedarach Linn) pada media tailing tambang emas pongkor. Tesis. Program pascasarjana USU, Sumatra Utara.

[26] Suhariyono, G., Y. Menry, 2005. Analisis karakteristik unsur-unsur dalam tanah di berbagai lokasi dengan menggunakan XRF. Dalam: Prosiding PPI-PDIPTN 2005; 2005 Jul 12. Jogyakarta, Puslitbang Teknologi Maju-BATAN, pp 197-206.

[27] Tisdale, S. L., W. L. Nelson, J. D. Beaton, 1990. Soil Fertility and Fertilizers ${ }^{\text {th }}$ Edition. Macmillan Publishing Company, New York.

[28] Wang, F. Y., X. G. Lin, R. Yin, 2007. Effect of arbuscular mycorrhizal fungal inoculation on heavy metal accumulation of maize grown in a naturally contaminated soil. International Journal of Phytoremediation 9, pp. 345-353.

[29] Widaningrum, Miskiyah, Suismono., 2007. Bahaya kontaminasi logam berat dalam sayuran dan alternatif pencegahan cemarannya. Buletin Teknologi Pascapanen Pertanian (3), pp. 16-27.

[30] Widyati, E., 2011. Potensi tumbuhan bawah sebagai akumulator logam berat untuk membantu rehabilitasi lahan bekas tambang. Mitra Hutan Tanaman 6(2), pp. 47-56. 